\title{
Peran self regulated learning dan task commitment terhadap prestasi akademik remaja akhir yang kuliah dan bekerja paruh waktu di Denpasar dan Badung
}

\author{
Ni Luh Kade Nadia Rastafary dan I Made Rustika \\ Program Studi Psikologi, Fakultas Kedokteran, Universitas Udayana \\ imaderustika@gmail.com
}

\begin{abstract}
Abstrak
Prestasi akademik merupakan indikator utama keberhasilan sebuah proses pendidikan, utamanya bagi remaja akhir. Manfaat prestasi akademik yang tinggi bagi remaja yaitu mempermudah dalam mendapatkan pekerjaan yang layak, meningkatkan kematangan karier, meningkatkan kemampuan pengambilan keputusan karier secara optimal, mempercepat masa studi dan membuka kesempatan penerimaan beasiswa. Namun tidak semua remaja mampu meraih prestasi akademik tinggi, salah satunya disebabkan oleh rutinitas lain di luar jam perkuliahan yakni bekerja. Keberhasilan remaja yang menjalankan perkuliahan sambil bekerja dalam meraih prestasi akademik tinggi tidak terlepas dari pengaturan strategi belajar yang baik dan komitmen yang tinggi terhadap tugas. Penelitian ini bertujuan untuk mengetahui peran self regulated learning dan task commitment terhadap prestasi akademik remaja akhir yang kuliah sambil bekerja di Denpasar dan Badung.

Subjek dalam penelitian ini adalah 185 orang mahasiswa yang sedang menjalankan kegiatan perkuliahan sambil bekerja di Denpasar dan Badung. Pengumpulan data dilakukan dengan arsip Indeks Prestasi Kumulatif, skala Self Regulated Learning dan skala Task Commitment. Teknik analisis data yang digunakan dalam penelitian ini adalah regresi berganda. Hasil uji regresi berganda menunjukkan nilai koefisien regresi sebesar 0,353 , nilai koefisien determinasi sebesar 0,125 dan nilai signifikansi sebesar $0,000(\mathrm{p}<0,05)$, dengan koefisien beta terstandarisasi pada variabel self regulated learning sebesar 0,354 dan task commitment sebesar -0,001. Hasil tersebut menunjukkan bahwa self regulated learning dan task commitment secara bersama-sama berperan terhadap prestasi akademik remaja akhir yang kuliah sambil bekerja di Denpasar dan Badung.
\end{abstract}

Kata kunci: remaja akhir, self regulated learning, task commitment, prestasi akademik

\begin{abstract}
Academic achievement is a major indicator of the success of an educational process, especially for the late adolescents. High academic achievement leads to decent jobs, helps increasing adolescents' career maturity, improving their career and decision-making capabilities optimally, accelerating their study period and increasing their opportunity for scholarship. However, not all college students are able to achieve high academic achievement, it caused by other routines outside the hours of lectures, such as working. The success of achieving high academic achievements on college students who works daily depends on good learning strategy and high commitment to every task given. This study aims to determine the role of self-regulated learning and task commitment towards academic achievement of late adolescents (college students who works daily) in Denpasar and Badung.

The subjects were 185 college students who works daily in Denpasar and Badung. Archives of Grade Point Average (GPA), Self Regulated Learning scale and Task Commitment scale were used to collect the data. Data analysis technique used in this research was multiple regression. The result of multiple regression test shows that the regression coefficient value is 0.353 , the determination coefficient value is 0.125 and the significance value is $0.000(p<0,05)$, with standardized beta coefficient on self-regulated learning variable equal to 0,354 and task commitment equal to $-0,001$. These results indicate that self-regulated learning and task commitment do simultaneously contribute towards academics achievement of late adolescents (college students who works daily) in Denpasar and Badung.
\end{abstract}

Key words: late adolescence, self-regulated learning, task commitment, academics achievement 


\section{N.L.K.N RASTAFARY DAN I.M RUSTIKA}

\section{LATAR BELAKANG}

Prestasi akademik merupakan indikator utama keberhasilan sebuah proses pendidikan. Hal ini dikarenakan prestasi akademik merupakan hasil dari suatu usaha peserta didik yang menggambarkan sejauh mana kemampuan peserta didik dalam mencapai tujuan yang telah ditetapkan dalam tiap bidang studi. Dikemukakan pula oleh Novanto (2015), bahwa prestasi akademik merupakan gambaran kualitas pendidikan nasional karena mengukur keberhasilan proses belajar mengajar yang dilaksanakan di lembaga pendidikan tertentu. Menurut Nurman (dalam Siregar, 2006) mutu output mahasiswa dari suatu jenjang pendidikan dapat dilihat dari prestasi akademiknya.

Pada masa remaja, prestasi akademik merupakan salah satu hal yang penting. Hal ini dikarenakan prestasi akademik yang diperoleh akan menjadi awal bagi para remaja untuk menempuh langkah-langkah selanjutnya (Santrock, 2007). Prestasi akademik yang diperoleh di masa sekolah akan memengaruhi kualitas institusi pendidikan tinggi yang akan ditempuh selanjutnya. Semakin tinggi prestasi belajar yang diperoleh, maka kemungkinan remaja untuk dapat belajar di institusi yang lebih baik dan banyak diminati juga lebih tinggi. Kedudukan peringkat dalam prestasi akademik juga menjadi suatu hal yang membanggakan dan diinginkan oleh banyak orangtua. Begitu pula pada mahasiswa di perguruan tinggi, prestasi akademik seperti hasil Indeks Prestasi Kumulatif (IPK) merupakan patokan mahasiswa untuk menilai dirinya terkait keberhasilan dalam menjalani perkuliahan.

Tingginya prestasi akademik memberikan beberapa manfaat positif bagi remaja. Menurut Nurman, Sihaloho, Yenni, Pinem \& Ponirin (1994), prestasi akademik sangat memengaruhi masa depan seorang remaja dan pilihan karirnya, sehingga hal ini menyebabkan tingginya prestasi akademik dapat mempermudah jalan remaja untuk mendapatkan pekerjaan yang layak. Wicaksono (2009) menyatakan bahwa prestasi akademik yang tinggi pada remaja berkaitan dengan tingginya kematangan karier dan menjadikan remaja mampu melakukan pengambilan keputusan karier secara optimal. Pada program studi dengan sistem pembelajaran SKS (Satuan Kredit Semester), prestasi akademik juga dijadikan sebagai acuan jumlah SKS yang dapat ditempuh mahasiswa pada tiap semester. Semakin tinggi prestasi akademik, semakin banyak SKS yang dapat ditempuh mahasiswa sehingga akan mempercepat masa studi. Sebagian besar bantuan dana beasiswa juga menggunakan prestasi akademik sebagai salah satu kriteria penerima beasiswa, sehingga remaja dengan prestasi akademik tinggi akan lebih berpeluang dalam memperoleh beasiswa.

Pada kenyataannya, masih banyak remaja yang belum mampu meraih prestasi akademik tinggi. Terdapat berbagai faktor yang menghambat mahasiswa untuk meraih prestasi akademik tinggi, salah satunya kuliah sambil bekerja. Kuliah sambil bekerja bukan merupakan hal yang baru pada remaja, utamanya remaja akhir. Hal ini dikarenakan remaja akhir merupakan masa persiapan akhir untuk memasuki peran-peran orang dewasa, selama periode ini remaja akan menetapkan tujuan vokasional dan mengembangkan sense of personal identity (Agustiani,
2009). Pada masa remaja akhir, orangtua biasanya menganggap remaja sudah hampir dewasa dan berada di ambang perbatasan untuk memasuki dunia kerja orang dewasa, melanjutkan pendidikan tinggi sebagai mahasiswa atau menerima pelatihan kerja tertentu (Hurlock, 1980).

Provinsi Bali sendiri merupakan provinsi dengan jumlah mahasiswa tertnggi di wilayah Kepulauan Nusa Tenggara yakni sejumlah 148.166 mahasiswa pada tahun 2017 (Kementerian Riset, Teknologi, dan Pendidikan Tinggi Republik Indonesia, 2017). Tercantum pada Perda Provinsi Bali No.16 tahun 2009 tentang RTRW Provinsi Bali 2009-2029 (dalam Lesmana, 2015), Kota Denpasar merupakan ibu kota Provinsi Bali yang berkembang pesat menjadi pusat kegiatan pemerintahan, bisnis, distribusi barang dan jasa, pusat pelayanan kesehatan serta pusat pendidikan. Lebih lanjut, tercantum pula dalam Laporan Tahunan Kopertis VIII tahun 2010 (dalam Lesmana, 2015), Kota Denpasar dan Kabupaten Badung di samping sebagai wilayah bisnis dan wisata juga merupakan wilayah pusat pendidikan di Provinsi Bali, hal ini ditandai dengan adanya perguruan tinggi negeri dan perguruan tinggi swasta yang tersebar di Kota Denpasar dan Kabupaten Badung. Terdapat sejumlah 40 perguruan tinggi negeri dan swasta.

Berdasarkan survei yang dilakukan oleh Endsleigh and the National Union of Students pada tahun 2016, sebesar 77\% dari 4642 mahasiswa di Indonesia kuliah sambil bekerja (BBC Indonesia, 2016). Beragam alasan melatarbelakanginya, mulai dari masalah ekonomi sampai hanya karena ingin mengisi waktu luang (Yenni, 2007). Motivasi remaja tersebut berbedabeda, ada yang ingin membantu orangtua dalam membiayai kuliah, ingin hidup mandiri dan mencari pengalaman (Wahyono, 2004). Menurut Cohen (dalam Ronen, 2008) bentuk pekerjaan yang paling banyak dilakukan oleh mahasiswa adalah jenis pekerjaan paruh waktu (part-time work), yakni selama 20 hingga 40 jam dalam seminggu.

Kuliah dan bekerja paruh waktu banyak memberi dampak bagi mahasiswa, baik dampak positif maupun dampak negatif. Dampak positifnya adalah mahasiswa dapat membantu orangttua dalam biaya studi dan biaya hidup, memperoleh pengalaman kerja serta memperoleh kemandirian ekonomis (Motte \& Schwartz, 2009). Gleason (dalam Metriyana, 2014) mengemukakan bahwa kuliah sambil bekerja juga menyebabkan mahasiswa kekurangan waktu belajar dan menerima nilai yang lebih rendah. Hal ini didukung dengan penelitian yang dilakukan oleh Pujiyanto pada tahun 2005. Penelitian ini menunjukkan bahwa pada mahasiswa yang bekerja terjadi penurunan IPK dan SKS yang diambil di tiap semester. Penelitian yang dilakukan oleh Fang, Legaspi, Perez, Remigi \& Sengsourya pada tahun 2008 terhadap 100 mahasiswa juga menunjukkan bahwa mahasiswa yang bekerja memiliki waktu yang lebih sedikit untuk belajar sehingga berdampak pada IPK yang menurun.

Di sisi lain, tidak semua remaja yang kuliah dan bekerja paruh waktu menunjukkan penurunan prestasi akademik sebagai mahasiswa. Hal ini didukung oleh studi pendahuluan melalui metode wawancara terhadap enam orang mahasiswa perguruan tinggi di Denpasar dan Badung yang kuliah dan bekerja paruh 


\section{N.L.K.N RASTAFARY DAN I.M RUSTIKA}

waktu melalui proses random. Hasilnya, keempat responden mengaku sejak kuliah dan bekerja paruh waktu, prestasi akademik responden cenderung stabil bahkan meningkat dan tidak pernah terjadi penurunan IPK. Keempat responden juga memiliki IPK terakhir berada di atas 3,00. Hal ini dikarenakan responden dapat dengan baik mengatur jadwal, memiliki komitmen yang tinggi dan menggunakan potensi diri secara optimal dalam melakukan kedua kegiatan tersebut bersamasama setiap hari (Rastafary, 2017).

Keberhasilan seseorang untuk dapat berprestasi di bangku perkuliahan dan kegiatan bekerja tentu sangat ditentukan oleh kemampuan mengaktualisasikan potensi diri secara optimal. Zimmerman (1996) menyatakan salah satu aspek mental yang sangat menentukan keberhasilan mengaktualisasikan potensi diri adalah self regulated learning. Mahasiswa yang memiliki self regulated learning adalah mahasiswa yang secara metakognitif, motivasional, dan behavioral berperan aktif dalam proses belajar. Self regulated learning membuat mahasiswa mampu mengobservasi dan mengevaluasi cara belajar menjadi efektif, mampu memonitor diri, dan merancang strategi belajar. Strategi belajar mandiri yang cocok dengan karakteristik individu akan memengaruhi efektifitas proses belajar.

Hasil penelitian Elianawani dan Wahyuni (dalam Puspita, 2018) menunjukkan bahwa pemberian kebebasan memilih pola belajar sesuai dengan minat mahasiswa ternyata memberi kenyamanan belajar dan motivasi berkompetisi yang positif sehingga pencapaian belajar menjadi lebih baik. Mahasiswa dianggap cukup mampu mengobservasi dan mengevaluasi cara belajar menjadi efektif, serta merancang strategi belajar sesuai situasi yang sedang dihadapi sehingga menghasilkan prestasi akademik yang baik. Self regulated learning pun dapat memaksimalkan potensi akademik dalam diri seseorang sehingga nantinya akan memengaruhi hasil dari prestasi akademik di sekolah maupun perguruan tinggi.

Tinggi rendahnya prestasi akademik yang dicapai individu juga tidak terlepas dari komitmen yang dimiliki, dalam hal akademik khususnya komitmen terhadap tugas atau task commitment. Renzulli (dalam Hawadi, 2002) menyatakan bahwa task commitment atau komitmen pada tugas merupakan kemauan yang berasal dari dalam diri seseorang yang mendorongnya untuk tekun dan ulet, meskipun mengalami berbagai rintangan dan hambatan dalam menyelesaikan tugas yang telah menjadi tanggung jawabnya. Rendahnya keterikatan terhadap tugas dapat memunculkan kesenjangan antara potensi yang dimiliki dengan prestasi yang ditunjukkan (Hawadi, 2002). Hal ini diperkuat oleh penelitian yang dilakukan oleh Winarti pada tahun 2006 yang menunjukkan bahwa terdapat pengaruh yang signifikan antara task commitment dengan prestasi akademik.

Tidak dapat dipungkiri bahwa prestasi akademik yang dicapai masing-masing individu pada pendidikan formal selalu ada yang lebih tinggi dan lebih rendah. Tidak maksimalnya individu dalam mencapai prestasi akademik tentunya didasari oleh faktor-faktor tertentu. Berdasarkan paparan di atas, maka penelitian mengenai Peran Self Regulated Learning dan Task Commitment terhadap Prestasi Akademik Remaja Akhir yang
Kuliah dan Bekerja Paruh Waktu di Denpasar dan Badung menjadi penting untuk dilakukan.

\section{METODE PENELITIAN}

\section{Variabel dan Definisi Operasional}

Variabel bebas dalam penelitian ini adalah self regulated learning dan task commitment, dengan variabel tergantung adalah prestasi akademik. Adapun definisi operasional dari masing-masing variabel dalam penelitian ini adalah sebagai berikut :

Definisi Operasional Self Regulated Learning

Self regulated learning adalah kemampuan seseorang untuk meregulasi dan mengendalikan dirinya sendiri dalam proses belajar serta menyusun strategi-strategi belajar efektif, dimana strategi tersebut melibatkan aspek (1) kognitif, (2) motivasi dan (3) perilaku untuk mencapai prestasi belajar yang diharapkan. Taraf self regulated learning diukur menggunakan skala Self Regulated Learning (SRL). Semakin tinggi skor yang diperoleh, maka semakin tingi taraf self regulated learning subjek.

Definisi Operasional Task Commitment

Task commitment adalah motivasi yang berasal dari dalam diri individu untuk bertanggungjawab terhadap tugas dan menghadapi rintangan yang muncul dengan ketekunan dan keuletan dalam mencapai suatu tujuan. Task commitment tercermin dari (1) sikap tangguh, ulet dan tidak mudah bosan, (2) sikap mandiri tidak memerlukan dorongan dari luar dan bertanggung jawab, (3) menetapkan tujuan dan aspirasi yang realistis dengan risiko sedang, (4) sikap suka belajar dan memiliki hasrat untuk meningkatkan diri dan (5) hasrat untuk berhasil dalam bidang akademik. Taraf task commitment diukur menggunakan skala Task Commitment (TC). Semakin tinggi skor yang diperoleh, maka semakin tinggi taraf task commitment subjek.

Definisi Operasional Prestasi Akademik

Prestasi akademik merupakan taraf penguasaan materi kuliah yang dinyatakan dalam bentuk angka, yang merupakan nilai rata-rata dari nilai kognitif (pengetahuan), afektif (sikap) dan psikomotor (perilaku). Nilai rata-rata tersebut disebut juga Indeks Prestasi Kumulatif (IPK). IPK merupakan penilaian terhadap mahasiswa secara akademik melalui tugas atau tes, yang dilakukan dengan mengalikan SKS dan nilai dari seluruh mata kuliah yang ditempuh, lalu hasil penjumlahannya dibagi dengan jumlah total SKS yang ditempuh.

\section{Subjek}

Populasi pada penelitian ini adalah remaja akhir yang kuliah dan bekerja paruh waktu di Denpasar dan Badung. Subjek dalam penelitian ini memiliki kriteria sebagai berikut: subjek berusia 18 sampai 22 tahun saat penelitian dilakukan, subjek berstatus sebagai mahasiswa aktif di salah satu institusi pendidikan tinggi di Denpasar dan Badung saat penelitian dilakukan, subjek sedang bekerja paruh waktu selama 20 sampai 40 jam dalam satu minggu saat penelitian dilakukan

Teknik pengambilan sampel pada penelitian ini menggunakan teknik non-probability sampling yang digunakan untuk penelitian ini adalah jenis Purposive Sampling. Purposive Sampling adalah teknik pengambilan sampel sumber data 
dengan pertimbangan tertentu (Sugiyono, 2014). Jumlah sampel yang digunakan dalam penyusunan penelitian adalah minimal 60 orang sesuai dengan kriteria, jumlah ini sudah dianggap cukup banyak (Azwar, 2013).

\section{Tempat dan Waktu Penelitian}

Penelitian dilaksanakan pada tanggal 15 hingga 30 Oktober 2017 di wilayah Denpasar dan Badung. Sebelum penelitian dilaksanakan, data-data remaja akhir yang kuliah dan bekerja paruh waktu telah dikumpulkan dengan cara mendata langsung melalui kuesioner. Skala yang disebar dalam tahap pengambilan data penelitian ini terdiri dari tiga bagian, yaitu bagian pertama adalah kesediaan untuk berpartisipasi dalam penelitian dan identitas subjek; bagian kedua adalah petunjuk pengisian dan skala SRL; dan bagian ketiga adalah petunjuk pengisian dan skala TC. Kuesioner yang disebarkan berjumlah 185 buah dan seluruhnya dapat digunakan sebagai data penelitian.

\section{Alat Ukur}

Alat ukur dalam penelitian ini menggunakan 2 skala yaitu Skala Self Regulated Learning dan Skala Task Commitment. Skala Self Regulated Learning merupakan modifikasi dari skala Wolters (2003) yang telah dikembangakan oleh Riana (2014) dan terdiri dari 26 aitem, sedangkan Skala Task Commitment merupakan modikasi dari skala Hawadi (2002) dan terdiri dari 31 aitem. Pernyataan dalam penelitian ini menggunakan empat pilihan jawaban, yaitu: Sangat Sesuai (SS), Sesuai (S), Tidak Sesuai (TS) dan Sangat Tidak Sesuai (STS). Taraf prestasi akademik dilihat dari arsip Indeks Prestasi Kumulatif (IPK), yang kemudian akan disetarakan dengan menggunakan skor standar yakni skor $\mathrm{T}$ sehingga menjadi skor variabel prestasi akademik.

Azwar (2015) menyatakan bahwa alat ukur yang valid dan reliabel merupakan syarat mutlak untuk mampu menghasilkan data dan memberikan informasi yang akurat. Pengukuran terhadap validitas isi dalam penelitian ini dilakukan melalui professional judgement untuk melakukan penyesuaian aitemaitem dalam alat ukur dengan indikator perilaku yang hendak diukur (Azwar, 2014). Pengukuran validitas konstruk dengan melihat koefisien korelasi aitem total sama dengan atau lebih besar daripada 0,30 . Uji reliabilitas alat ukur dilakukan dengan metode Alpha Cronbach, dikatakan reliablel apabila koefisien reliabilitas minimal 0,60 (Azwar, 2014).

Hasil uji validitas skala self regulated learning memiliki koefisien korelasi aitem-total berkisar antara 0,293 sampai 0,624 . Pada skala task commitment, koefisien korelasi aitemtotal berkisar antara 0,319 sampai 0,593. Uji reliabilitas skala self regulated learning menunjukkan koefisien reliabilitas sebesar 0,859. Angka tersebut menunjukkan bahwa skala ini mampu mencerminkan $85,90 \%$ variasi yang terjadi pada skor murni subjek terkait sehingga alat ukur dinyatakan layak digunakan untuk mengukur atribut self regulated learning. Uji reliabilitas skala task commitment menunjukkan koefisien reliabilitas sebesar 0,903. Angka tersebut menunjukkan bahwa skala ini mampu mencerminkan $90,30 \%$ variasi yang terjadi pada skor murni subjek terkait sehingga alat ukur dinyatakan layak digunakan untuk mengukur atribut task commitment.

\section{Teknik Analisis Data}

Teknik analisis data dalam penelitian ini menggunakan analisis Regresi Berganda dengan bantuan program SPSS 20.0 for Windows. Sebelum melakukan analisis data penelitian dilakukan uji asumsi data yang mencakup uji normalitas, uji linearitas dan uji multikolinearitas. Uji normalitas dilakukan dengan menggunakan uji Kolmogorov-Smirnov pada program SPSS 20.0 for Windows. Uji linearitas dilakukan dengan menggunakan Test of Linearity pada program SPSS 20.0 for Windows, sedangkan uji multikolinearitas dilakukan dengan menggunakan nilai Variance Inflation Factor (VIF) dan nilai Tolerance pada program SPSS 20.0 for Windows.

\section{HASIL PENELITIAN}

\section{Karakteristik Subjek}

Subjek dalam penelitian ini merupakan remaja akhir yang kuliah dan bekerja paruh waktu di Denpasar dan Badung yang berjumlah 185 orang. Mayoritas subjek dalam penelitian ini berusia 21 tahun $(68,10 \%)$, berjenis kelamin perempuan $(61,10 \%)$, pendidikan terakhir Ayah adalah S1 (42,16\%), pendidikan terakhir Ibu adalah S1 (52,97\%), merupakan mahasiswa Universitas Udayana (48,64\%), memiliki taraf IPK antara 3,00 hingga $3,50(46,48 \%)$ dan telah bekerja selama lebih dari 12 bulan $(34,05 \%)$.

\section{Deskripsi Data Penelitian}

Dari hasil deskripsi statistik data penelitian dapat dijelaskan makna nilai-nilai yang dipaparkan sebagai berikut:

Self regulated learning

Hasil deskripsi statistik pada Tabel 1 menunjukkan bahwa self regulated learning memiliki mean teoretis sebesar 65,00 dan mean empiris sebesar 73,68. Perbedaan mean empiris dan mean teoretis variabel self regulated learning sebesar 8,68 dengan nilai $\mathrm{t}$ sebesar 12,991 $(\mathrm{p}=0,000)$. Hal ini menunjukkan perbedaan yang signifikan antara mean empiris dan mean teoretis. Mean empiris yang diperoleh lebih besar dari mean teoretis (mean empiris $>$ mean teoretis) menghasilkan sebuah kesimpulan bahwa subjek memiliki taraf self regulated learning yang tinggi.

Task comitment

Hasil deskripsi statistik pada Tabel 1 menunjukkan bahwa task commitment memiliki mean teoretis sebesar 77,50 dan mean empiris sebesar 93,24. Perbedaan mean empiris dan mean teoretis variabel task commitment sebesar 15,74 dengan nilai t sebesar 23,049 $(\mathrm{p}=0,000)$. Hal ini menunjukkan perbedaan yang signifikan antara mean empiris dan mean teoretis. Mean empiris yang diperoleh lebih besar dari mean teoretis (mean empiris $>$ mean teoretis) menghasilkan sebuah kesimpulan bahwa subjek memiliki taraf task commitment yang tinggi.

Prestasi akademik

Hasil deskripsi statistik pada Tabel 1 menunjukkan bahwa prestasi akademik memiliki mean teoretis sebesar 50,00 dan mean empiris sebesar 49,9999. Perbedaan mean empiris dan mean teoretis variabel prestasi akademik adalah sebesar 0,0001 dengan nilai $t$ sebesar $0,000 \quad(p=0,999)$. Hal ini 


\section{N.L.K.N RASTAFARY DAN I.M RUSTIKA}

menunjukkan tidak terdapat perbedaan yang signifikan antara besarnya IPK dari masing-masing subjek penelitian.

\section{Uji Asumsi}

Uji Normalitas

Uji normalitas dilakukan untuk mengetahui normal atau tidaknya sebaran skor variabel. Uji normalitas dilakukan dengan menggunakan uji Kolmogorov-Smirnov pada program SPSS 20.0 for Windows. Sebaran data dapat dikatakan normal jika signifikansinya $\mathrm{p}>0.05$ dan sebaliknya dikatakan tidak normal jika signifikansinya $\mathrm{p}<0.05$ (Santosa, 2014). Hasil uji normalitas dapat dilihat pada Tabel 2 (terlampir).

Berdasarkan hasil uji normalitas, diperoleh hasil sebagai berikut: (1) Sebaran Data Variabel Self Regulated Learning Berdasarkan hasil uji normalitas, Tabel 2 menunjukkan bahwa data pada variabel self regulated learning berdistribusi normal dengan nilai Kolmogorov-Smirnov 0,745 dan signifikansi 0,636 ( $>0$,05); (2) Sebaran Data Variabel Task Commitment

Berdasarkan hasil uji normalitas, Tabel 2 menunjukkan bahwa data pada variabel task commitment berdistribusi normal dengan nilai Kolmogorov-Smirnov 0,695 dan signifikansi 0,720 ( $>0$,05); (3) Sebaran Data Variabel Prestasi Akademik

Berdasarkan hasil uji normalitas, Tabel 2 menunjukkan bahwa data pada variabel prestasi akademik berdistribusi normal dengan nilai Kolmogorov-Smirnov 0,889 dan signifikansi 0,409 ( $\mathrm{p}>0,05)$.

\section{Uji Linieritas}

Uji linearitas bertujuan untuk mengetahui apakah dua variabel yang dikenai prosedur analisis statistik korelasional menunjukkan adanya hubungan yang linear atau tidak. Uji linearitas dilakukan dengan menggunakan Test of Linearity pada program SPSS 20.0 for Windows. Hubungan dua variabel dikatakan signifikan linear jika $\mathrm{p}<0.05$ dan sebaliknya dikatakan tidak linear jika $\mathrm{p}>0.05$ (Priyanto, 2012). Hasil uji linearitas data penelitian dapat dilihat pada Tabel 3 (terlampir).

Hasil uji linearitas pada Tabel 3 menunjukkan bahwa terdapat hubungan yang linear antara variabel prestasi akademik dan variabel self regulated learning dengan signifikansi linearity sebesar $0,000(p<0,05)$ dan signifikansi deviation of linearity $0,914(\mathrm{p}>0,05)$. Begitu juga hubungan antara prestasi akademik dan task commitment linear dengan signifikansi linearity sebesar $0,005(\mathrm{p}<0,05)$ dan signifikansi deviation of linearity $0,980 \quad(p>0,05)$. Dengan demikian, dapat dikatakan bahwa terdapat hubungan linear antara prestasi akademik dengan self regulated learning serta prestasi akademik dengan task commitment.

\section{$\underline{\text { Uji Multikolinearitas }}$}

Menurut Ghozali (2005), uji multikolinearitas digunakan untuk menguji apakah dalam model regresi ditemukan adanya korelasi yang tinggi antar variabel bebas. Model regresi yang baik seharusnya tidak terjadi korelasi yang tinggi di antara variabel bebas. Identifikasi multikolinearitas dapat diketahui dari nilai Variance Inflation Factor (VIF) dan nilai Tolerance. Nilai Tolerance yang rendah sama dengan nilai VIF yang tinggi ( $\mathrm{VIF}=1 /$ Tolerance). Jika nilai VIF $₫ 10$ dan nilai Tolerance 0,1, maka dinyatakan tidak terjadi multikolinearitas. Uji multikolinearitas dilakukan menggunakan bantuan perangkat lunak SPSS 20.0 for Windows. Hasil uji multikolinearitas dapat dilihat pada Tabel 4 (terlampir).

Hasil uji multikolinearitas yang ditunjukkan pada Tabel 4 menunjukkan bahwa variabel self regulated learning dan task commitment memiliki nilai tolerance sebesar 0,628 dan nilai VIF sebesar 1,592, sehingga dapat dikatakann bahwa tidak terjadi multikolinearitas.

\section{Uji Hipotesis}

Hipotesis dalam penelitian ini diuji dengan menggunakan teknik analisis regresi berganda. Analisis regresi berganda adalah teknik yang digunakan untuk menguji hipotesis tentang hubungan dua variabel independen atau lebih secara bersamasama dengan satu variabel dependen dengan jenis data interval dan rasio (Sugiyono, 2014). Uji regresi berganda dilakukan dengan bantuan SPSS 20.0 for Windows dengan melihat nilai koefisien regresi R, uji F, dan koefisien beta. Hasil uji hipotesis data penelitian dapat dilihat pada Tabel 5, Tabel 6 dan Tabel 7 (terlampir).

Hasil uji regresi berganda pada Tabel 5 menunjukkan koefisien regresi $\mathrm{R}$ sebesar 0,353 dan koefisien determinasi ( $\mathrm{R}$ square) sebesar 0,125 . Maka dapat dikatakan bahwa self regulated learning dan task commitment secara bersama-sama menentukan $12,5 \%$ taraf prestasi akademik, sedangkan $87,5 \%$ sisanya ditentukan oleh variabel lain yang tidak diteliti.

Pada Tabel 6, dapat dilihat nilai $\mathrm{F}$ yang dihasilkan dari uji regresi berganda sebesar 12,952 dan signifikansi sebesar 0,000 $(\mathrm{p}<0,05)$. Dengan demikian, model regresi dalam penelitian ini dapat digunakan untuk memprediksi prestasi akademik. Kesimpulan yang didapatkan adalah bahwa self regulated learning dan task commitment secara bersama-sama berperan terhadap prestasi akademik.

Hasil uji regresi berganda pada Tabel 7 menunjukkan bahwa self regulated learning memiliki koefisien beta terstandarisasi sebesar 0,354, nilai $\mathrm{t}$ sebesar 4,040 dan signifikansi 0,000 $(\mathrm{p}<0,05)$, sehingga self regulated learning berperan secara signifikan terhadap prestasi akademik. Task commitment memiliki koefisien beta yang terstandarisasi sebesar $-0,001$, nilai t sebesar -0,010 dan signifikansi sebesar 0,992 $(\mathrm{p}<0,05)$ sehingga task commitment tidak berperan secara signifikan terhadap prestasi akademik.

\section{PEMBAHASAN DAN KESIMPULAN}

Berdasarkan hasil penelitian yang telah dipaparkan, hasil analisis dengan menggunakan teknik regresi berganda menunjukkan bahwa pengujian hipotesis mayor adanya peran self regulated learning dan task commitment pada remaja akhir yang kuliah dan bekerja paruh waktu di Denpasar dan Badung dapat diterima. Hal ini dapat dilihat dari hasil nilai koefisien $\mathrm{R}$ sebesar 0,353 serta nilai $\mathrm{F}$ hitung sebesar 12,952 dengan taraf signifikansi $0,000 \quad(p<0,05)$. Selain itu, terdapat koefisien determinasi yang menunjukkan nilai sebesar 0,125 yang menunjukkan bahwa variabel self regulated learning dan task commitment memberi sumbangan efektif sebesar 12,5\% terhadap prestasi akademik remaja akhir yang kuliah dan 
bekerja paruh waktu di Denpasar dan Badung, sedangkan sisanya sebesar $87,5 \%$ dipengaruhi oleh variabel lain yang tidak diteliti.

Self regulated learning membuat mahasiswa mampu mengobservasi dan mengevaluasi cara belajar menjadi efektif, mampu memonitor diri, disiplin, mandiri dan merancang strategi belajar (Zimmerman, dkk., 1996). Remaja akhir yang menerapkan self regulated learning akan mampu mengulang materi pelajaran yang didapatkan di perkuliahan secara rutin, merancang jadwal belajar yang diikuti secara konsisten, memiliki usaha untuk mempelajari materi lebih dalam dengan menanyakan kepada orang lain yang dianggap mampu, membagi waktu secara efektif untuk bisa menyelesaikan tugas tepat waktu, menyusun goals atau target pencapaian, serta mengevaluasi hasil prestasi akademik. Hal ini sejalan dengan penelitian yang dilakukan oleh Sitepu pada tahun 2014 mengenai pengaruh self regulated learning terhadap prestasi akademik mahasiswa yang aktif berorganisasi di Universitas Sumatera Utara. Hasil penelitian menunjukkan bahwa terdapat pengaruh self regulated learning terhadap prestasi akademik mahasiswa yang aktif berorganisasi.

Remaja akhir yang memiliki peran tidak hanya sebagai mahasiswa tetapi juga bekerja, dalam kenyataannya dapat memiliki prestasi akademik yang memuaskan ditandai dengan Indeks Prestasi Kumulatif (IPK) yang tergolong tinggi, hal ini tidak terlepas dari regulasi belajar mandiri yang mahasiswa lakukan (Rachmah, 2015). Schaie dan Carstensen (2006) juga mengemukakan bahwa mahasiswa dengan peran lain yang dimiliki akan melakukan regulasi diri dalam belajar yang lebih tinggi daripada mahasiswa yang tidak memiliki peran lain. Mahasiswa meskipun telah bekerja tetap melakukan regulasi diri dalam belajar agar lebih mudah memahami materi. Motivasi untuk menguasai materi, tidak adanya perasaan terpaksa dalam belajar serta pengaturan materi pelajaran yang relevan untuk aplikasi di kehidupan kerja membuat regulasi diri dalam belajar dapat terlaksana (Mezei, 2008).

Prestasi akademik pada remaja yang kuliah dan bekerja paruh waktu juga dipengaruhi oleh task commitment. Task commitment adalah motivasi internal yang mendorong seseorang untuk tekun dan ulet mengerjakan tugas, meskipun mengalami macam-macam rintangan, secara khusus adalah tugas akademik (Munandar, 2004). Individu dengan task commitment akan terdorong untuk tekun dan ulet mengerjakan tugasnya meskipun mengalami macam-macam rintangan dalam menyelesaikan tugas yang menjadi tanggungjawabnya karena individu tersebut telah mengikat diri terhadap tugas tersebut atas kehendak sendiri (Rijal dan Bachtiar, 2015).

Task commitment tinggi juga dicirikan dengan perilaku gemar belajar dan selalu memiliki hasrat untuk meningkatkan kualitas diri. Hal ini terlihat dari perilaku senang, rajin dan semangat dalam belajar, mampu mempertahankan pendapat saat berdiskusi dan senantiasa menetapkan standar kerja yang tinggi. Dengan demikian, semakin tinggi task commitment dalam diri mahasiswa, maka makin tinggi pula prestasi akademiknya. Dikemukakan pula oleh Hawadi (2002) bahwa rendahnya task commitment dapat memunculkan kesenjangan antara potensi yang dimiliki dengan prestasi yang ditunjukkan, sehingga task commitment memengaruhi prestasi akademik. Hal ini sejalan dengan penelitian yang dilakukan oleh Kholiq pada tahun 2015 mengenai task commitment pada mahasiswa yang kuliah sambil bekerja sebagai guru. Hasil penelitian menunjukkan bahwa perilaku aktual task commitment mampu menghasilkan productivity yang diukur melalui IPK dengan predikat Sangat Baik.

Hasil koefisien beta terstandarisasi menunjukkan bahwa variabel self regulated learning memiliki koefisien beta terstandarisasi sebesar 0,354 , nilai $\mathrm{t}$ sebesar 4,040 dan signifikansi $0,000(\mathrm{p}<0,05)$, sehingga self regulated learning berperan secara signifikan terhadap prestasi akademik. Self regulated learning merupakan suatu strategi seseorang untuk mampu meregulasi diri dalam aktivitas belajar dengan tujuan menghasilkan prestasi akademik yang memuaskan.

Remaja akhir dengan dua rutinitas seperti kuliah dan bekerja paruh waktu membutuhkan kemampuan self regulated learning untuk mempertahankan prestasi akademik yang optimal. Selain menyadari gaya belajar yang sesuai dengan keadaan seperti gaya belajar visual, auditorial, dan kinestetik untuk menunjang prestasi belajar, kemampuan meregulasi diri dalam belajar juga tidak kalah penting untuk diterapkan agar remaja mampu mengatur diri dan menentukan strategi belajar yang cocok dengan situasi yang dihadapi sehingga mampu menghasilkan prestasi akademik yang lebih optimal.

Hasil penelitian Elianawani dan Wahyuni (dalam Puspita, 2018) menunjukkan bahwa pemberian kebebasan memilih pola belajar sesuai dengan minat mahasiswa ternyata memberi kenyamanan belajar dan motivasi berkompetisi yang positif sehingga pencapaian belajar menjadi lebih baik. Remaja dianggap cukup mampu mengobservasi dan mengevaluasi cara belajar agar efektif, serta merancang strategi belajar sesuai situasi yang sedang dihadapi sehingga menghasilkan prestasi akademik yang baik.

Disiplin pada jadwal belajar dapat membuat mahasiswa menggunakan waktu secara efektif sehingga tetap bisa membagi waktu untuk kegiatan ekstra lainnya. Individu dengan regulasi yang baik juga mampu mengatur materi yang dipelajari agar dapat meningkatkan efektivitas proses pembelajaran dan mengubah materi pelajaran menjadi lebih sederhana dan mudah dipelajari. Remaja dengan self regulatd learning tinggi juga memiliki kemampuan untuk mengevaluasi diri dalam belajar seperti tidak mengulang strategi belajar yang salah atau mengevaluasi kekurangan dari hasil pencapaian prestasi akademik. Begitu pula sebaliknya, remaja yang memiliki self regulated learning rendah cenderung mengalami kesulitan untuk mengatur jadwal dan strategi belajar yang efektif dan tidak mampu mengevaluasi strategi belajar yang paling sesuai, sehingga prestasi akademik yang diraih pun cenderung tidak optimal.

Variabel task commitment memiliki nilai koefisien beta terstandarisasi sebesar $-0,001$, nilai $\mathrm{t}$ sebesar $-0,010$ dan signifikansi sebesar $0,992(\mathrm{p}<0,05)$ sehingga task commitment tidak berperan secara signifikan terhadap prestasi akademik. 


\section{N.L.K.N RASTAFARY DAN I.M RUSTIKA}

Task commitment merupakan energi dalam diri yang mendorong seseorang untuk tekun dan ulet mengerjakan tugasnya meskipun mengalami macam-macam rintangan dalam menyelesaikan tugas yang menjadi tanggung jawabnya karena individu tersebut telah mengikat diri terhadap tugas tersebut atas kehendak sendiri.

Menurut Hurlock (1980), saat memasuki usia remaja, inidividu mengalami perubahan emosi, tubuh, minat, peran, pola perilaku, perubahan pada nilai-nilai yang dianut, dan menginginkan kebebasan. Apabila remaja terlalu fokus dengan salah satu minat dan perannya seperti bekerja, remaja dapat memiliki kecenderungan untuk mengesampingkan kewajiban lainnya sebagai seorang mahasiswa. Bila seorang remaja memiliki komitmen yang tinggi terhadap tugas yang diberikan dalam pekerjaan namun tidak disertai dengan komitmen pada perannya sebagai seorang mahasiswa dan pengaturan strategi belajar yang sesuai dengan remaja tersebut, maka prestasi akademik yang optimal akan sulit dicapai. Komitmen yang tinggi terhadap tugas yang diberikan dalam pekerjaan juga berisiko menjadikan remaja menomorduakan kegiatan perkuliahan serta tugas yang diberikan dalam perkuliahan.

Remaja dengan taraf self regulated learning tinggi akan memiliki motivasi tersendiri untuk dapat mencapai prestasi yang diharapkan. Remaja memiliki inisiatif yang tinggi untuk menggali informasi terkait pelajaran dengan cara aktif bertanya pada teman sebaya, guru, dan orang dewasa lainnya sehingga dapat memperluas wawasan. Remaja memiliki motif ekstrinsik yang disebut ego-enhancement, yaitu ambisi pribadi untuk meningkatkan prestasi dirinya dengan cara meraih indeks prestasi setinggi-tingginya (Syah, 2014). Motivasi yang remaja miliki dapat menjadi pemicu dalam mengembangkan keterampilan belajar yang cerdik dan efisien. Seorang remaja dengan self regulated learning tinggi memiliki kolaborasi antara kognitif, afektif, dan motivasional untuk meraih pencapaian akademik yang diharapkan.

Hal ini sejalan dengan hasil uji regresi berganda yang dilakukan oleh Sucipto (2014) mengenai pengaruh self regulated learning dan dukungan orangtua terhadap prestasi akademik peserta didik pada mata pelajaran ekonomi program studi IPS SMA Negeri di kota Jombang. Penelitian ini menyatakan bahwa variabel self regulated learning lebih dominan mempengaruhi hasil belajar dibandingkan dengan variabel dukungan orangtua.

Prestasi akademik merupakan taraf penguasaan materi kuliah yang dinyatakan dalam bentuk angka, yang diperoleh dari ratarata nilai kognitif, afektif, dan psikomotor sehingga penting adanya kedisiplinan belajar maupun tingkat inteligensi yang dapat mendukung pencapaian prestasi akademik yang optimal. Bila remaja hanya terpaku dengan komitmen pada tugas seperti perasaan keterlibatan yang tinggi dengan tugas yang diberikan namun tidak diimbangi dengan pengelolaan diri agar dapat mengerjakan tugas tersebut dengan baik, maka remaja cenderung tidak mampu meraih prestasi akademik yang optimal.

Terlebih lagi remaja yang kuliah dan bekerja paruh waktu memiliki jadwal yang lebih padat dibandingkan remaja yang kuliah saja atau bekerja saja, sehingga untuk mencapai prestasi akademik yang optimal, remaja yang kuliah dan bekerja paruh waktu lebih membutuhkan kedisiplinan diri dalam belajar untuk meraih nilai yang memuaskan. Hal tersebut menyebabkan self regulated learning dalam belajar berkontribusi lebih besar terhadap pencapaian prestasi akademik dibandingkan dengan task commitment.

\section{Kesimpulan}

Berdasarkan penelitian dan analisis data yang telah dilakukan, maka dapat ditarik kesimpulan sebagai berikut:

1. Self regulated learning dan task commitment secara bersamasama berperan terhadap prestasi akademik remaja akhir yang kuliah dan bekerja paruh waktu di Denpasar dan Badung.

2. Self regulated learning berperan terhadap prestasi akademik remaja akhir yang kuliah dan bekerja paruh waktu di Denpasar dan Badung.

3. Task commitment tidak berperan secara signifikan terhadap prestasi akademik remaja akhir yang kuliah dan bekerja paruh waktu di Denpasar dan Badung.

4. Self regulated learning remaja akhir yang kuliah dan bekerja paruh waktu di Denpasar dan Badung tergolong tinggi.

5. Task commitment remaja akhir yang kuliah dan bekerja paruh waktu di Denpasar dan Badung tergolong tinggi.

6. Prestasi akademik remaja akhir yang kuliah dan bekerja paruh waktu di Denpasar dan Badung tergolong sedang.

\section{Saran}

\section{$\underline{\text { Saran Praktis }}$}

Remaja akhir khususnya yang menjalankan kuliah dan bekerja paruh waktu diharapkan dapat mempertahankan dan meningkatkan kemampuan regulasi belajar mandiri sehingga tetap mampu meraih prestasi akademik yang optimal. Hal ini dapat dilakukan dengan cara menerapkan regulasi belajar mandiri seperti bertanya kepada pihak lain yang dianggap mampu memberikan informasi mengenai materi perkuliahan yang mungkin sempat terlewatkan karena bekerja, menentukan jadwal belajar yang tidak berbenturan dengan waktu kerja dan mengulang materi pelajaran agar lebih mudah diingat.

Orangtua diharapkan mampu mengarahkan anak yang kuliah dan bekerja paruh waktu untuk tetap menerapkan regulasi belajar mandiri sehingga dapat menjalankan tugas utama sebagai mahasiswa dengan baik. Pengarahan yang diberikan dapat berupa edukasi mengenai contoh-contoh penerapan regulasi belajar mandiri yang baik. Orangtua diharapkan mampu mengingatkan anak untuk tidak hanya fokus pada pekerjaan atau kegiatan non-akademik, melainkan tetap mengingat tugas utama sebagai mahasiswa yaitu belajar dengan memberikan informasi dan pengertian tentang pentingnya pencapaian prestasi akademik serta pentingnya keseimbangan soft-skill dan hard-skill untuk menghasilkan keberhasilan yang optimal

Pihak Fakultas dan Universitas diharapkan memberikan pembekalan tentang rekomendasi seperti pemberian sosialisasi mengenai regulasi belajar mandiri yang efektif dari pihak profesional agar dapat mempertahankan dan meningkatkan prestasi akademik pada remaja akhir, khususnya yang 
menjalankan kuliah dan bekerja paruh waktu.

Saran Bagi Peneliti Selanjutnya

Peneliti selanjutnya diharapkan dapat meneliti perbedaan prestasi akademik, self regulated learning, dan task commitment remaja akhir yang menjalankan kuliah dan bekerja paruh waktu dengan remaja akhir yang menjalankan kuliah saja. Peneliti selanjutnya diharapkan dapat melakukan penelitian serupa dengan subjek yang lebih bervariasi dan dengan cakupan daerah yang lebih luas. Peneliti selanjutnya diharapkan dapat meneliti variabel psikologis lainnya yang

memengaruhi tinggi-rendahnya prestasi akademik remaja akhir seperti efikasi diri, motivasi berprestasi, prokrastinasi akademik, dukungan sosial, resiliensi dan lain-lain.

\section{DAFTAR PUSTAKA}

Agustiani, H. (2009). Psikologi perkembangan: pendekatan ekologi kaitannya dengan konsep diri dan penyesuaian diri pada remaja. Bandung: Refika Aditama.

Azwar, S. (2014a). Reliabilitas dan validitas. Yogyakarta: Pustaka Belajar.

Azwar, S. (2014b). Dasar-dasar psikometri. Yogyakarta: Pustaka Belajar.

BBC Indonesia. (2016). Mahasiswa yang bekerja sambil kuliah meningkat. Diunduh dari http://www.bbc.com/indonesia/majalah/2015/08/150810_m ajalah pendidikan mahasiswa. Diakses pada 21 Januari 2017.

Fang, Legaspi, Perez, Remigio \& Sengsourya.(2008). Factors affecting GPA. Diunduh dari http://public.csusm.edu/fangfang/Teaching/BUS304/TeamP resentation Spr08/Report_Group3.pdf . Diakses pada 20 November 2016

Ghozali, I. (2005). Aplikasi analisis multivariate dengan program SPSS. Semarang: Badan Penerbit Universitas Diponegoro

Hawadi, R. A. (2002). Identifikasi keberbakatan intelektual melalui metode non-tes: Dengan pendekatan konsep keberbakatan renzulli. Jakarta: Gramedia Widiasarana Indonesia.

Hurlock, E. B. (1980). Psikologi perkembangan: suatu pendekatan sepanjang rentang kehidupan edisi kelima. Terjemahan Instiwidayanti dan Soedjarwo. Jakarta: Erlangga.

Kementerian Riset, Teknologi dan Pendidikan Tinggi Republik Indonesia. (2017). Statistik pendidikan tinggi. Diunduh dari http://kopertis3.or.id/v5/wp-content/uploads/Buku-StatistikPendidikan-Tinggi-2017.pdf. Diakses 3 Juli 2018.

Kholiq, M. A. (2015). Task commitment mahasiswa yang berkuliah sambil bekerja sebagai guru dalam mencapai keberhasilan belajar program S1 di setia walisembilan semarang. (Skripsi Tidak Dipublikasikan). Fakultas Psikologi Universitas Katolik Soegijapranata.

Lesmana, P. S. W. (2015). Pengaruh perkembangan dua lokasi kampus universitas udayana terhadap perkembangan fasilitas wilayah sekitarnya. (Tesis Tidak Dipublikasikan). Universitas Gajah Mada.

Metriyana, M. (2014). Studi komparatif pengaruh motivasi, perilaku belajar, self-efficacy dan status kerja terhadap prestasi akademik antara mahasiswa tidak bekerja. (Skripsi Tidak Dipublikasikan). Universitas Diponegoro.

Mezei, G. (2008). Motivation and self-regulated learning: A case study of a pre-intermediate adult student. WoPaLP. 2, 79-104.

Motte, A., \& Schwartz, S. (2009). Are student employment and academic success linked?. Canada: Millennium Research
Note. Diunduh dari http://www.millenniumscholarships.ca/. Diakses pada 25 Januari 2017.

Munandar, U. (2002). Pengembangan kreativitas anak berbakat. Jakarta: Rineka Cipta.

Novanto, Y. (2015). Motivasi belajar, penyesuaian diri, kepuasan mahasiswa dan prestasi akademik mahasiswa penerima beasiswa di universitas $X$. Publikasi Ilmiah Seminar Nasional Psikologi Universitas Muhammadiyah Surakarta. (1), 165-174.

Nurman, A., Sihaloho, L., Yenni, Pinem, M. B., \& Ponirin. (1994). Kontribusi kondisi ekonomi orang tua, biaya kost, motivasi profesi terhadap indeks prestasi (IP) mahasiswa FPIPS IKIP Medan. Laporan Penelitian Medan. 6-7.

Puspita, S.A.L., \& Rustika, I. M. (2018). Peran self regulated learning dan konsep diri terhadap prestasi akademik mahasiswa remaja akhir fakultas kedokteran universitas udayana yang pernah menjadi finalis bali pageants. Jurnal Psikologi Udayana. 5(1), 1-11.

Rachmah, D. N. (2015). Regulasi diri dalam belajar pada mahasiswa yang memiliki peran banyak. Jurnal Psikologi. 42(1). 61-77.

Rastafary, N. (2017). Studi pendahuluan: kendala akademik mahasiswa universitas udayana yang kuliah sambil bekerja. (Naskah Tidak Dipublikasikan). Fakultas Kedokteran Universitas Udayana.

Riana, P.R., \& Rustika, I.M. (2016). Hubungan antara self regulated learning dan kelekatan remaja awal terhadap Ibu dengan prestasi belajar siswa SMP N 6 Denpasar. Jurnal Psikologi Udayana. 3(1). 54-63.

Rijal, S., \& Bachtiar, S. (2015). Hubungan antara sikap, kemandirian belajar dan gaya belajar dengan hasil belajar kognitif siswa. Jurnal Bioedukatika. 3(2). 15-20.

Ronen, S. (1981). Flexible working hours: an innovation in the quality of work life. USA: Mc.Graw-Hill Book Company.

Santrock, J. W. (2007). Remaja: Edisi kesebelas. Jakarta: Erlangga.

Schaie, K. W., \& Carstensen, L. L. (2006). Social structure, aging and self-regulation in the elderly. New York: Springter Publishing Company.

Siregar, R. (2006). Pengaruh indeks prestasi kumulatif dan persepsi mahasiswa akuntansi kota Medan mengenai beberapa faktor tertentu terhadap pilihan karir. (Tesis Publikasi). Universitas Sumatera Utara Medan. 15-16.

Sitepu, C. F. (2014). Pengaruh self regulated learning terhadap prestasi akademik mahasiswa yang aktif berorganisasi di universitas sumatera utara. (Skripsi Tidak Dipublikasikan). University of Sumatera Utara Institutional Repository.

Sucipto. (2014). Pengaruh self regulated learning dan dukungan orang tua terhadap hasil belajar peserta didik pada mata pelajaran ekonomi program studi IPS SMA Negeri di kota Jombang. Jurnal Ekonomi Pendidikan dan Kewirausahaan. 2 (2), 237-251.

Sugiyono. (2014). Metode penelitian kombinasi (Mixed methods). Bandung: Alfabeta

Syah, M. (2014). Psikologi pendidikan dengan pendekatan baru. Bandung: PT Remaja Rosdakarya.

Wahyono. (2004). Kuliah sambil bekerja. Pikiran Rakyat 11 Juni 2004. Diunduh dari

http://www.pikiranrakyat.com/index.php?mib=topik\&id=9. Diakses pada 21Januari

2017.

Wicaksono. (2009). Pengaruh kepercayaan diri, motivasi belajar sebagai akibat dari latihan bola voli terhadap prestasi belajar atlet di sekolah. (Tesis Tidak Dipublikasikan). Program Pascasarjana Universitas Negeri Yogyakarta.

Yenni, D. (2007). Kuliah sambil kerja, why not?. Majalah Medan Bisnis 1: Jakarta. 


\section{N.L.K.N RASTAFARY DAN I.M RUSTIKA}

Zimmerman, B. J., Bonner, S., \& Kovach, R. (1996). Developing self regulated learners:Beyond achievement to self efficacy. Washington: American Psychological Association. 


\section{LAMPIRAN}

Tabel 1

Deskripsi statistik data penelitian

\begin{tabular}{ccccccccc}
\hline Variabel & N & $\begin{array}{c}\text { Mean } \\
\text { Teoritis }\end{array}$ & $\begin{array}{c}\text { Mean } \\
\text { Empiris }\end{array}$ & $\begin{array}{c}\text { Std } \\
\text { Deviasi } \\
\text { Teoritis }\end{array}$ & $\begin{array}{c}\text { Std. } \\
\text { Deviasi } \\
\text { Empiris }\end{array}$ & $\begin{array}{c}\text { Sebaran } \\
\text { Tearitis }\end{array}$ & $\begin{array}{c}\text { Sebaran } \\
\text { Empiris }\end{array}$ & t \\
\hline SRL & 185 & 65,00 & 73,68 & 13,00 & 9,089 & $26-104$ & $50-95$ & $\begin{array}{c}12,991 \\
(\mathrm{p}=0,000)\end{array}$ \\
\hline TC & 185 & 77,50 & 93,24 & 15,50 & 9,287 & $31-124$ & $68-116$ & $\begin{array}{c}23,049 \\
(\mathrm{p}=0,000)\end{array}$ \\
\hline PA & 185 & 50,00 & 49,9999 & 10,00 & 9,99976 & $0-100$ & $\begin{array}{c}17,45- \\
68,35\end{array}$ & $\begin{array}{c}0,000 \\
(\mathrm{p}=1,000)\end{array}$ \\
\hline
\end{tabular}

Tabel 2

Hasil uji normalitas data penelitian

\begin{tabular}{ccc}
\hline Variabel & KalonogonowSmirnof. & Asymp.Sig (2-tailed) \\
\hline Self Regulated Learning & 0,745 & 0,636 \\
\hline Task Commitment & 0,695 & 0,720 \\
\hline Prestasi Akademik & 0,889 & 0,409 \\
\hline
\end{tabular}

Tabel 3

Hasil uji linieritas data penelitian

\begin{tabular}{|c|c|c|c|c|}
\hline & & & $\mathbf{F}$ & Sig. \\
\hline $\begin{array}{c}\text { Prestasi } \\
\text { Akademik }{ }^{*} \text { Self }\end{array}$ & Between Groups. & Linearity & 24,333 & 0,000 \\
\hline $\begin{array}{l}\text { Resulated } \\
\text { Learning }\end{array}$ & & $\begin{array}{l}\text { Dexiation of } \\
\text { Linearity }\end{array}$ & 0,683 & 0,914 \\
\hline $\begin{array}{c}\text { Prestasi } \\
\text { Akademik }{ }^{*} \text { Task }\end{array}$ & Between Groups. & Lineaxity & 7,998 & 0,005 \\
\hline Commitment & & $\begin{array}{l}\text { Dexiation of } \\
\text { Linearity }\end{array}$ & 0,574 & 0,980 \\
\hline
\end{tabular}

Tabel 4

Hasil uji multikolinier data penelitian

\begin{tabular}{cccc}
\hline Variabel & Tolerance & $\begin{array}{c}\text { Variance Inflation } \\
\text { Eactor (VIF) }\end{array}$ & Keterangan \\
\hline $\begin{array}{c}\text { Self Regulated } \\
\text { Learning }\end{array}$ & 0,628 & 1,592 & $\begin{array}{c}\text { Tidak terjadi } \\
\text { multikolinearitas }\end{array}$ \\
\hline Task Sammitment & 0,628 & 1,592 & $\begin{array}{c}\text { Tidak terjadi } \\
\text { multikolinearitas }\end{array}$ \\
\hline
\end{tabular}


Tabel 5

Hasil uji regresi berganda

\begin{tabular}{cccc}
\hline $\boldsymbol{R}$ & $\boldsymbol{R}$ Square & Adjusted $\boldsymbol{R}$ Square & Std Errox af the Estimate \\
\hline $\mathbf{0 , 3 5 3}$ & 0,125 & 0,115 & 9,40759 \\
\hline
\end{tabular}

Tabel 6

Hasil uji regresi berganda signifikansi nilai $\mathrm{F}$

\begin{tabular}{cccccc}
\hline & Sum of & Df & Mean & F & Sig. \\
& Squares & & Squares & & \\
\hline Regression & 2292,506 & 2 & 1146,253 & 12,952 & 0,000 \\
Residual & 16107,494 & 182 & 88,503 & & \\
Total & 18400,00 & 184 & & & \\
\hline
\end{tabular}

Tabel 7

Hasil uji regresi berganda nilai koefisien beta dan nilai t variabel self regulated learning dan task commitment terhadap prestasi akademik

\begin{tabular}{|c|c|c|c|c|c|}
\hline Model & $\begin{array}{l}\text { Unstandaxized } \\
\text { Caefficients } \\
\text { B }\end{array}$ & Std Exrar & $\begin{array}{c}\text { Standarized } \\
\text { Caefficients. } \\
\text { Beta }\end{array}$ & $\mathbf{t}$ & Sige. \\
\hline (Constant) & 21,432 & 7,209 & & 2,973 & 0,003 \\
\hline $\begin{array}{l}\text { Self Regulated } \\
\text { Learning }\end{array}$ & 0,389 & 0,096 & 0,354 & 4,040 & 0,000 \\
\hline $\begin{array}{c}\text { Task } \\
\text { Compmitment }\end{array}$ & $-0,001$ & 0,094 & $-0,001$ & $-0,010$ & 0,992 \\
\hline
\end{tabular}

